\title{
AKTYWIZACJA SPOŁECZNA I ZAWODOWA OSADZONYCH JAKO ISTOTA ODDZIAKYWAŃ PROBACYJNYCH W ŚRODOWISKU WOLNOŚCIOWYM
}

\begin{abstract}
Socio-professional activation of the imprisoned as the essence of probationary interventions in a libertarian environment

Staying in prison isolation - in a total institution is sometimes a time of many changes in human life. A new, previously unknown place in which "second life" takes place can contribute to fears, fears, lowered sense of life, lack of goals. Therefore, to counteract the negative consequences of imprisonment, it is worthwhile to introduce activities aimed at social and occupational activation, which significantly reduce the level of anxiety and give a new meaning. Ryszard Musidłowski writes that it is worth emphasizing that "although the purpose of the penalty of deprivation of liberty is primarily the resocialisation of the sentenced person, and not merely the desire to cooperate in shaping his social attitudes, he assumes and prefers his activity."
\end{abstract}

Key words: probation, social activation, professional activation, local environment

\section{Wprowadzenie}

Aktywizacja społeczna i zawodowa to determinanty, które w znaczny sposób wpływają na skuteczność prowadzonych działań reintegracyjnych w środowisku wolnościowym. To bardzo ważne, aby dawać szansę na zmianę i poprawę zachowania osadzonych, a nie postrzegać ich stereotypowo i wykluczać. Aby taka sytuacja miała rację bytu, należy przede wszystkim stworzyć możliwości i warunki do zmiany zachowania sprawcy. Dzięki takiemu postępowaniu osadzeni mają szansę poznania wartości, zasad i norm etyczno-moralnych akceptowanych i oczekiwanych w życiu wolnościowym. Jedną z podstawowych wartości w życiu człowieka, która w istotny sposób wpływa na zmianę postaw, a zarazem wzmacnia i nadaje sens życiu, jest praca. W literaturze przedmiotu praca definiowana jest jako „świadoma działalność człowieka skierowana ku realizacji wybranych celów, wyznaczonych dla poszczególnych jednostek lub zbiorowości” (Szymańska 2007: 11-12). Zdaniem Zygmunta Wiatrowskiego (1997: 57): 
każdy człowiek sprawny fizycznie i psychicznie ma prawo do pracy, a organizacja życia społecznego powinna gwarantować realizację tego prawa; każdy człowiek winien uzyskać takie przygotowanie do pracy i taki stan kompetencji, które zagwarantują mu szansę bycia podmiotem w każdej sytuacji pracowniczej; każdy pracujący ma prawo do pozyskania w drodze pracy zawodowej minimum środków gwarantujących jemu i jego najbliższym stan ludzkiej egzystencji; niedostatek pracy, a więc bezrobocie, powstaje na skutek gry czynników ekonomicznych, godzi w istotę człowieka, zdolnego i pragnącego realizować swoje naturalne prawo do pracy oraz związane z tym powinności zawodowe.

W związku z powyższym praca jest nieodzownym elementem prawidłowego funkcjonowania człowieka w społeczeństwie. Dzięki pracy jednostka ma szansę samorealizacji, podnoszenia swoich kompetencji społecznych i zawodowych oraz przede wszystkim ma możliwość zdobywania doświadczenia, które w perspektywie czasu staje się bezcenną umiejętnością warunkującą usamodzielnienie i niezależność. Celem niniejszego artykułu jest wskazanie, jak ważną rolę w procesie readaptacji osób osadzonych odgrywa możliwość zatrudnienia już w trakcie osadzenia oraz po opuszczeniu jednostek penitencjarnych.

\section{Praca w warunkach wolnościowych - regulacje prawne i przykłady oddziaływań}

Praca w warunkach wolnościowych to przykład działań aktywizujących zarówno społecznie, jak i zawodowo skazanych. Zdarza się tak, że praca podjęta w ramach odbywania kary pozbawienia wolności jest pierwszą pracą w życiu osadzonego. Dlatego też wszelkie działania zmierzające do usamodzielnienia przede wszystkim opierają się na edukacji, podniesieniu kwalifikacji zawodowych bądź też przekwalifikowaniu zawodowym (Stępniak 2008). Edukacja w jednostkach penitencjarnych z jednej strony jest formą pracy, która ma na celu aktywizację społeczną i zawodową skazanych, z drugiej natomiast jest kluczowym elementem procesu resocjalizacji.

W Kodeksie karnym wykonawczym (kkw) praca jest pierwszym i najważniejszym środkiem oddziaływania resocjalizacyjnego. To dzięki pracy osadzony nabywa umiejętności i kompetencje niezbędne do późniejszego funkcjonowania w systemie społecznym.

Zgodnie $\mathrm{z}$ art. $121 \mathrm{kkw}$ :

- $\$ 1$. Skazanemu zapewnia się w miarę możliwości świadczenie pracy.

- \$2. Skazanego zatrudnia się na podstawie skierowania do pracy albo umożliwia się skazanemu wykonywanie pracy zarobkowej w ramach umowy o pracę, umowy zlecenia, umowy o dzieło, umowy o pracę nakładczą lub na innej podstawie prawnej.

Zgodnie z powyższym wyraźnie podkreślono wystandaryzowane możliwości, jakie jednostki penitencjarne oferują osadzonym. Aby jednak skazany mógł podjąć pracę, niezbędne jest spełnienie określonych wymogów formalnych. Wówczas dopiero konkretny więzień jest delegowany do konkretnej pracy (na terenie jednostki bądź też w warunkach wolnościowych). 
Zgodnie z art. 123:

- \$1. Praca skazanego jest odpłatna, z zastrzeżeniem art. 123a nieodpłatna praca skazanego. Zasady wynagradzania za pracę ustala się w porozumieniu zawieranym przez dyrektora zakładu karnego lub w umowie zawieranej przez skazanego. Przy skierowaniu skazanego do prac administracyjno-porządkowych na terenie zakładu karnego wynagrodzenie za pracę ustala dyrektor tego zakładu. - \$2. Wynagrodzenie przysługujące skazanemu zatrudnionemu w pełnym wymiarze czasu pracy ustala się w sposób zapewniający osiągnięcie kwoty co najmniej minimalnego wynagrodzenia za pracę ustalanego na podstawie odrębnych przepisów, przy przepracowaniu pełnego miesięcznego wymiaru czasu pracy lub wykonaniu pełnej miesięcznej normy pracy. W wypadku przepracowania niepełnej miesięcznej normy czasu pracy lub niewykonania pełnej miesięcznej normy pracy wynagrodzenie wypłaca się proporcjonalnie do ilości czasu pracy lub wykonanej normy pracy. W razie zatrudnienia skazanego w niepełnym wymiarze czasu pracy najniższe wynagrodzenie ustala się w kwocie proporcjonalnej do liczby godzin zatrudnienia, biorąc za podstawę kwotę minimalnego wynagrodzenia za pracę (Ustawa z dnia 6 czerwca 1997 r. Kodeks karny wykonawczy [Dz. U. 1997.90.557]).

Dzięki powyższemu zapisowi można zauważyć, że skazani oprócz nieodpłatnego zatrudnienia mają też możliwość wykonywania pracy, za którą otrzymują wynagrodzenia. Wówczas jest to szansa na zgromadzenie środków, które mogą być przeznaczone na usamodzielnienie w warunkach wolnościowych. Bardzo często osadzeni, z którymi rozmawiałam, podkreślali, że „dzięki pracy czas za kratami nie jest zmarnowany i dzień szybciej mija”. Dodatkowo możliwość zarabiania własnych pieniędzy jest bezpośrednio związana $\mathrm{z}$ treningiem ekonomicznym i nauką racjonalnego wydatkowania środków. Pomimo iż, jak wielu osadzonych podkreśla, „są to niewielkie pieniądze”, przyczyniają się jednak w dużej mierze do usamodzielnienia w warunkach wolnościowych.

Szczegółowe kwestie związane z zatrudnianiem skazanych regulują przepisy rozporządzenia Ministra Sprawiedliwości z dnia 6 czerwca 2011 roku w sprawie szczegółowych zasad zatrudniania skazanych.

Konkludując, zapisy w powyższych regulacjach prawnych, umożliwienie zatrudniania w trakcie odbywania kary pozbawienia wolności niewątpliwie są pierwszym krokiem zmierzającym do skuteczności oddziaływań readaptacyjnych w środowisku wolnościowym. To bardzo ważne, aby w ramach procesu resocjalizacji skazani mieli możliwość podjęcia pracy, ponieważ Nihil agendo homines, male agerediscunt, co oznacza, że „Nic nie czyniąc, ludzie uczą się źle czynić” (Dubiński 2005: 325). Słowa te wyraźnie wskazują na wielowymiarowość pracy ludzkiej. Poprzez pracę z jednej strony skazany ma wypełniony i zagospodarowany nadmiar czasu wolnego, a z drugiej otrzymuje szansę rozwoju własnej osoby, poznania swoich możliwości, a także ograniczeń. Brak możliwości zatrudnienia, jak pisze Zygmunt Bauman (2010: 153):

oznacza, że jest się potencjalnym, a może nawet faktycznym odrzutem, kimś - ostatecznie i nieodwołanie - uznanym za odpad postępu gospodarczego, owej zmiany, która w ostatecznym rachunku 
sprowadza się do wykonywania tej samej pracy i uzyskiwania tych samych efektów gospodarczych, tyle że przy udziale mniejszej liczby pracowników i obniżonych kosztach pracy.

Biorąc pod uwagę założenia prawne, zgodnie z $\$ 2$ Rozporządzenia Ministra Sprawiedliwości z dnia 13 lutego 2004 r., w zakładach karnych i aresztach śledczych prowadzi się nauczanie skazanych i tymczasowo aresztowanych w celu zapewnienia im możliwości uzyskania wykształcenia podstawowego i gimnazjalnego, a także możliwości zdobycia wiedzy ogólnej i kwalifikacji zawodowych w szkołach ponadpodstawowych (ponadgimnazjalnych) albo uzyskania umiejętności i kwalifikacji w formach pozaszkolnych (Rozporządzenie Ministra Sprawiedliwości z dnia 13 lutego 2004 r. w sprawie szczegółowych zasad i trybu prowadzenia nauczania w zakładach karnych [Dz. U. Nr 37, poz. 337]). Natomiast na podstawie art. $76 \$ 1$ pkt 5 Kodeksu karnego wykonawczego jednym z podstawowych zadań komisji penitencjarnej jest właśnie kwalifikacja skazanych do nauczania w szkołach i na kursach. Zgodnie z informacją, jaką podaje Służba Więzienna, osadzony, w celu podjęcia nauki w szkole występuje z wnioskiem do komisji penitencjarnej o skierowanie do nauczania. Komisja penitencjarna, kwalifikując osadzonego do nauczania w określonym typie szkoły, kieruje się w szczególności:

1. udokumentowaną dotychczasową nauką stanowiącą podbudowę programową konieczną do podjęcia nauki w wybranym typie szkoły lub semestrze nauki;

2. motywacją i predyspozycjami do nauki w odpowiednim typie szkoły;

3. zaleceniami zawartymi $\mathrm{w}$ indywidualnym programie oddziaływania;

4. zaleceniami wynikającymi z przeprowadzonych badań psychologicznych, o ile takie badania zostały przeprowadzone;

5. ogólnym stanem zdrowia, ocenionym przez lekarza zatrudnionego w więziennej służbie zdrowia;

6. terminem warunkowego przedterminowego zwolnienia lub końca kary;

7. dotychczasowym stażem pracy osadzonego w wybranym zawodzie;

8. zgodnością wybranego przez osadzonego typu szkoły i kierunku kształcenia z wykazem szkół i aktualnym, na dany semestr, wykazem kierunków kształcenia i semestrów nauki w szkołach;

9. przeznaczeniem jednostki penitencjarnej, przy której funkcjonuje wybrana przez osadzonego szkoła;

10. koniecznością zapewnienia porządku i bezpieczeństwa w zakładzie (http://sw.gov.pl/pl/o-sluzbie-wieziennej/edukacja-skazanych, dostęp: 20.09.2017).

Osadzonych kwalifikuje się do nauczania w szkole, jeżeli czas pozostały do zakończenia odbywania kary nie jest krótszy niż okres trwania nauki w szkole. Do wszystkich typów szkół można ponadto kwalifikować osadzonych warunkowo, jeżeli do terminu zwolnienia z zakładu karnego w związku z przedterminowym warunkowym zwolnieniem lub końcem kary pozostało im nie mniej niż 6 miesięcy, a wymagają oni ukończenia przerwanej nauki lub mają odpowiednią motywację do nauki i możliwość jej kontynuowania po opuszczeniu zakładu karnego. Przyjmowanie osadzonych do szkół prowadzonych przy zakładach następuje na podstawie wyników postępowania rekrutacyjnego, prowadzonego 
przez szkolną komisję rekrutacyjną. Przy rekrutowaniu kandydatów na semestr pierwszy w szkołach nie przeprowadza się egzaminów wstępnych i rozmów kwalifikacyjnych. Pierwszeństwo w przyjmowaniu do szkoły mają:

- osadzeni odbywający karę pozbawienia wolności w systemie programowanego oddziaływania, którym w indywidualnym programie oddziaływania określono potrzebę nauczania;

- osadzeni, którym pozostaje do końca kary okres krótszy lub równy okresowi nauki w szkole. Warunkiem przyjęcia osadzonego do szkoły prowadzącej kształcenie zawodowe jest uzyskanie przez niego zaświadczenia lekarskiego stwierdzającego brak przeciwwskazań zdrowotnych do podjęcia nauki w wybranym zawodzie (http://sw.gov.pl/pl/o-sluzbie-wieziennej/edukacja-skazanych, dostęp: 20.09.2017).

Niewątpliwie dla wielu osadzonych możliwość zagospodarowania czasu wolnego poprzez umożliwienie kontynuacji nauki jest szansą na nabycie lub podniesienie swoich kompetencji społecznych i zawodowych niezbędnych w przyszłym, wolnościowym funkcjonowaniu. Edukacja, dla wielu osadzonych, jest szansą na zmianę dotychczasowych priorytetów i przyzwyczajeń. W znacznym stopniu wpływa również na kształtowanie aspiracji, wyznaczanie celów oraz adaptację do zmieniających się warunków społecznych.

\section{Empowerment jako czynnik wzmacniający proces aktywizacji}

W świetle skuteczności oddziaływań edukacyjnych i ich wpływu na aktywizację społeczną i zawodową warto zwrócić uwagę na istotę empowerment (tłum. upełnomocnienie) w pracy socjalnej jako czynnika wzmacniającego rozwój kompetencji społecznych. Koncepcja empowerment powstała w wyniku badań Martina Seligmana i Lyna Abramsona nad osobami, u których występował „syndrom wyuczonej bezradności”. Biorąc pod uwagę środowisko więzienne i fakt, że wśród niektórych osadzonych wyraźnie można zaobserwować ów syndrom, tym bardziej warto akcentować ideę i założenia tej koncepcji. Empowerment

przesuwa centrum zainteresowania problemami społecznymi i egzystencjonalnymi współczesności z tego, kim człowiek jest, w kierunku tego, kim się staje, uwzględniając adaptacyjny aspekt rozwoju człowieka, w którego centrum pozostaje pojęcie zmiany, wzajemnej zależności i równowagi dynamicznej (Gawęcka 2004).

Empowerment opiera się na przekonaniu, że istotą oddziaływań motywujących człowieka do zmiany jest wzmocnienie jego kompetencji (Gulczyńska, Granosik 2014). Biorąc pod uwagę osadzonych, myślę, że również oni mają określone kompetencje, które jednak nie zawsze zostały odkryte. Stąd też edukacja, podnoszenie kwalifikacji i nabywanie nowych umiejętności w znaczny sposób wpływają na wzmocnienie i ujawnienie dotychczas nieznanych kompetencji. Poniżej zaprezentuję własną propozycję kompleksowego 
modelu aktywizacji społecznej i zawodowej osadzonych, który opracowałam na podstawie wieloletnich obserwacji i analiz badawczych.

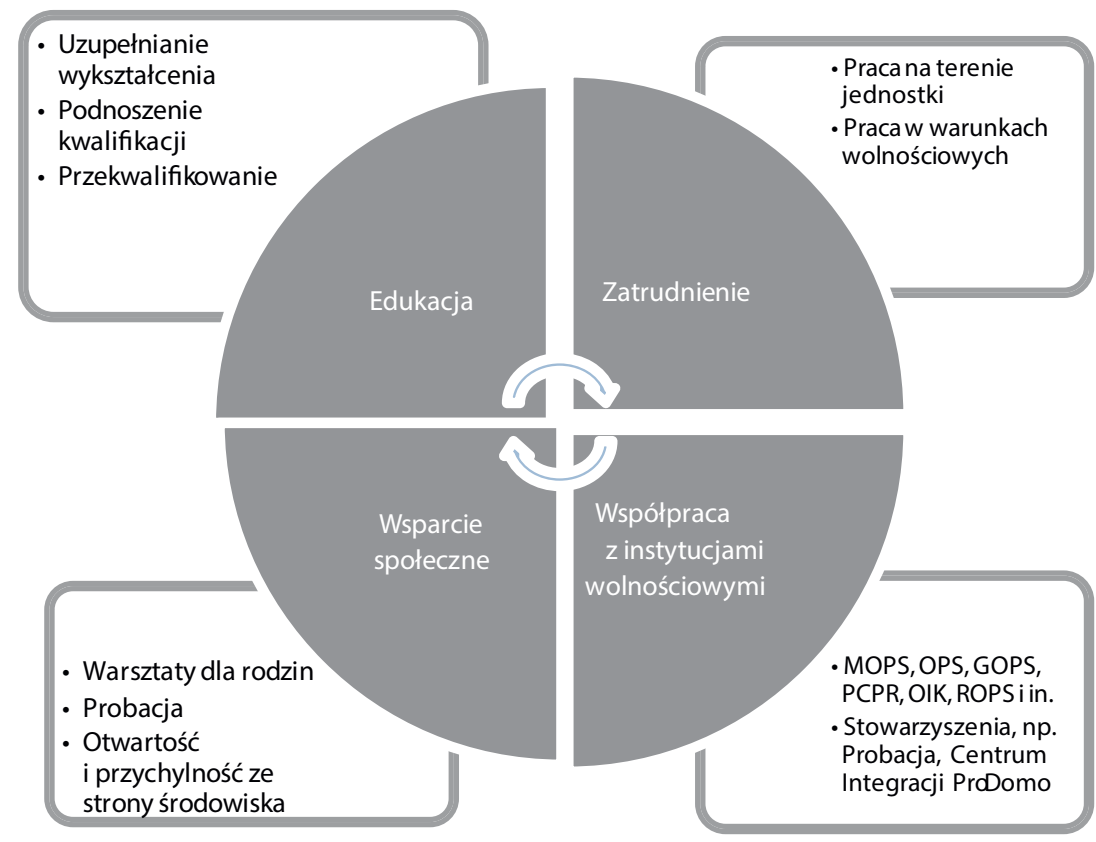

Rysunek 1. Model aktywizacji społeczno-zawodowej osadzonych

Źródło: Opracowanie własne.

Zaproponowany przeze mnie model aktywizacji społecznej i zawodowej osadzonych zawiera wiele istotnych elementów: od edukacji, wsparcia społecznego, zatrudnienia, aż po współpracę z instytucjami wolnościowymi. Owa interdyscyplinarność jest podstawą skuteczności oddziaływań readaptacyjnych i aktywizacyjnych w środowisku, Szczególny nacisk położyłam na istotę edukacji (w tym przede wszystkim uzupełnianie i podnoszenie kwalifikacji oraz przekwalifikowanie zawodowe $\mathrm{w}$ trakcie odbywania kary), możliwości zatrudnienia zarówno na terenie jednostek penitencjarnych, jak i w warunkach wolnościowych, współpracę z instytucjami rządowymi i pozarządowymi, a w głównej mierze skoncentrowałam się na roli wsparcia społecznego, ze szczególnym uwzględnieniem pracy z rodziną osób osadzonych.

Wszystkie wskazane przeze mnie elementy tworzą spójną całość, która wzajemnie z sobą współgra w różnych sytuacjach społecznych. Odnosząc się do tematu artykułu, należy zdecydowanie podkreślić rolę, jaką pełni możliwość zatrudnienia w procesie aktywizacji zawodowej. 


\section{Zatrudnienie osadzonych jako priorytet oddziaływań reintegracyjnych}

Ryszard Musidłowski (2007: 191) pisze, że najważniejszą sprawą, oprócz potrzeby zwiększenia zatrudnienia skazanych, jest wpojenie im przekonania, że powodzenie ich readaptacji społecznej w znacznej mierze zależy od ich aktywności i samodzielności w rozwiązywaniu swoich problemów.

Praca więźniów

Mapa planowanych do realizacji hal produkcyjnych

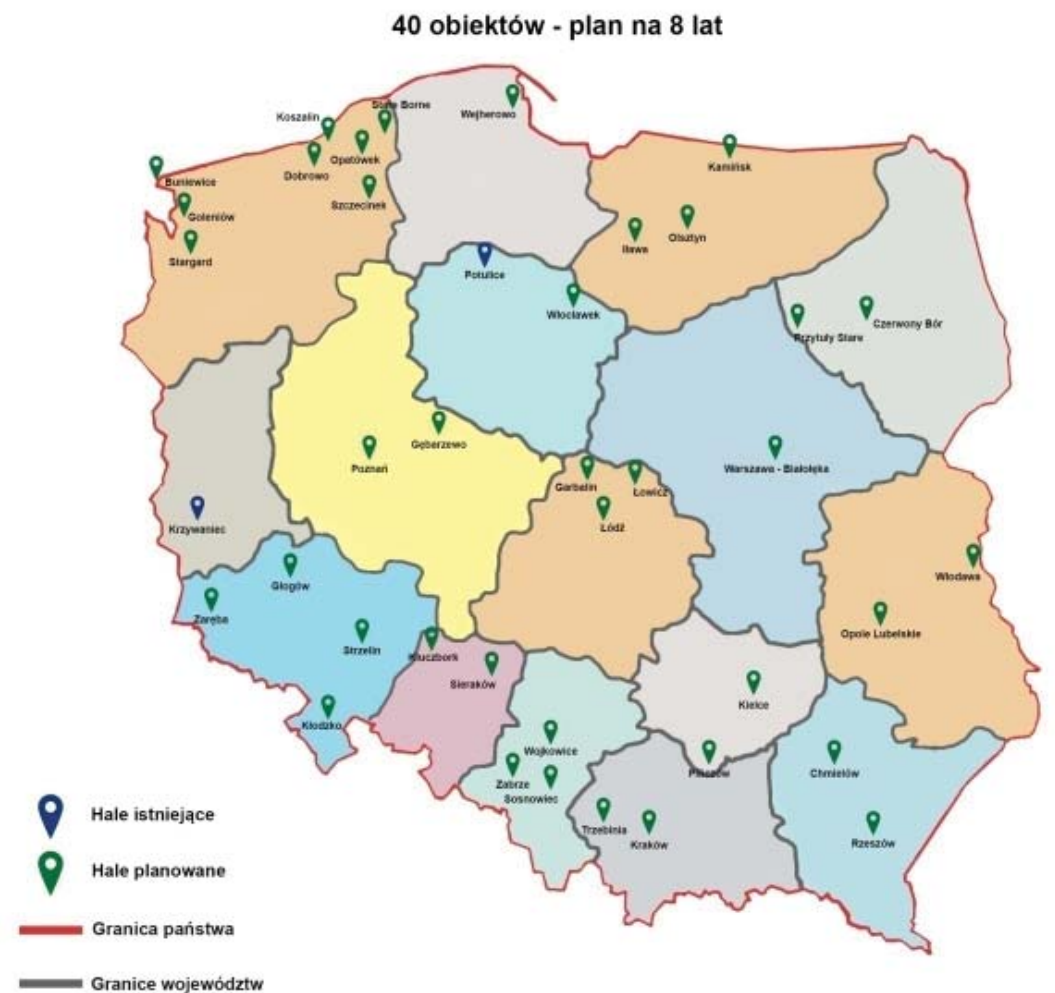

Rysunek 2. Mapa planowanych do realizacji hal produkcyjnych

Źródło: http://sw.gov.pl/pl/ministerialny-program-pracy-wiezniow (dostęp: 29.06.2017).

Biorąc pod uwagę zarówno kompetencje osobiste, jak i uzyskane w trakcie osadzenia kwalifikacje i doświadczenie zawodowe (praca osadzonych na terenie jednostek 
penitencjarnych oraz w warunkach wolnościowych), warto wskazać na priorytetową kwestię, jaką jest wspomniana przez Musidłowskiego samodzielność. W chwili zakończenia odbywania kary istotne jest bowiem jak najszybsze podjęcie zatrudnienia, tak aby osoba mogła w pełni się usamodzielnić i mieć cel, który nada sens dalszemu życiu. Jak pokazują dane Ministerstwa Sprawiedliwości, koszt utrzymania więźnia w Polsce to 3150 zł miesięcznie, a blisko $70 \%$ skazanych w ogóle nie pracuje.

Korzyści dla pracodawców przedstawione w ramach głównych założeń programu to:

- osobie pozbawionej wolności zatrudnionej w pełnym wymiarze godzin przysługuje wynagrodzenie zapewniające osiągnięcie co najmniej minimalnego wynagrodzenia za pracę, przy czym wynagrodzenie naliczane jest proporcjonalnie do faktycznie przepracowanych godzin;

- brak potrzeby zawierania indywidualnych umów o zatrudnieniu osób pozbawionych wolności (zatrudniony skazany nie staje się pracownikiem zatrudniającego w rozumieniu prawa pracy);

- pracodawca zwolniony jest z obowiązku stosowania przepisów prawa pracy (z wyjątkiem przepisów dotyczących czasu pracy oraz BHP);

- pracodawca jest zwolniony z obowiązku odprowadzania składki zdrowotnej za zatrudnienie osoby pozbawionej wolności;

- korzystanie z darmowej ochrony obiektów produkcyjnych zlokalizowanych na terenach ścisłych jednostek organizacyjnych Służby Więziennej;

- zatrudniający ma prawo wnioskowania o zmianę miejsca i rodzaju pracy lub o wycofanie osoby pozbawionej wolności z zatrudnienia bez zachowania formy i terminów przewidzianych w prawie pracy;

- osoby pozbawione wolności nie są objęte obowiązkowym ubezpieczeniem chorobowym;

- możliwość uzyskania dofinansowania działań prowadzących do tworzenia nowych miejsc pracy dla skazanych oraz na ochronę istniejących ze środków Funduszu Aktywizacji Zawodowej Skazanych oraz Rozwoju Przywięziennych Zakładów Pracy (http://sw.gov.pl/pl/ministerialny-program-pracy-wiezniow, dostęp: 20.09.2017).

Powyższe założenia pełnią ważną funkcję społeczną, mogą bowiem przyczynić się do obniżenia stereotypowego postrzegania osadzonych i etykietowania ich w związku z błędami, jakie popełnili w przeszłości (więcej Gucwa-Porębska 2015). Dodatkowo warto przedstawić także korzyści płynące z zatrudnienia dla samych osadzonych. Przede wszystkim jest to możliwość zdobycia doświadczenia zawodowego, poznania reguł i zasad pracowniczych, ale także jest to zmiana dotychczasowej rzeczywistości społecznej - z izolacyjnej na wolnościową. Jak podaje kpt. Bartłomiej Turbiarz z Zespołu Prasowego Służby Więziennej:

Więźniowie chcą pracować, ale również Służbie Więziennej zależy na tym, aby jak największa liczba osadzonych pracowała. Powodów jest kilka. Praca to najlepszy środek oddziaływań na osadzonych. Uczy przede wszystkim nawyku pracy, sumienności oraz obowiązkowości, czego osadzonym bardzo często brakuje. Osadzony, pracując, wie, że musi rano wstać, iść do pracy i tam sumiennie wykonywać obowiązki. Jeżeli te nawyki przeniesie na swoje normalne życie po wyjściu z więzienia, to już duży 
sukces. Poza tym praca daje więźniom możliwość zarobkowania i tym samym np. spłacania zadłużenia czy też zasądzonych alimentów. Praca jest też alternatywą dla więziennej nudy (http://forsal.pl/ artykuly/944306,tak-wyglada-rynek-pracy-wiezniow-w-polsce-kto-ich-zatrudnia-i-ile-zarabiaja. html, dostęp: 21.09.2017).

Odwołując się do powyższego stwierdzenia, wyraźnie widać pozytywne aspekty zatrudnienia osadzonych. Oczywiście myślę, że podobnie jak w innych dziedzinach życia społecznego zmiana dotychczasowych niepożądanych zachowań zależy w większości od decyzji człowieka, od jego wychowania, charakteru, motywacji i chęci zmiany. Mając powyższe na uwadze, nie sposób jednak wykluczyć pojawienia się u niektórych osób pewnych nadużyć i nieuczciwości, co może rzutować na ogół osób osadzonych. Dlatego też niezbędne i niezawodne w mojej opinii jest indywidualne podejście do każdej jednostki. Biorąc pod uwagę społeczne realia i dane, które pokazują, że

pracownicy i funkcjonariusze działów penitencjarnych i terapeutycznych w zakładach karnych i aresztach śledczych są znacznie obciążeni pracą z uwagi na zbyt dużą liczbę osadzonych przypadających na jednego wychowawcę (nawet 110 osób) i psychologa (nawet 369 osób). Pomimo to wykonują systematyczną pracę ze skazanymi, między innymi tworzą i prowadzą programy resocjalizacyjne, opracowują indywidualne programy oddziaływania, indywidualne programy terapeutyczne, organizują zajęcia sportowe, kulturalne (https://www.nik.gov.pl/aktualnosci/nik-o-readaptacji-spolecznej-skazanych-na-wieloletnie-kary-pozbawienia-wolnosci.html).

Jest to działanie bardzo trudne, a czasami wręcz niewykonalne w takiej skali, jaką by sobie założyli pracownicy. To bardzo ważne, aby wszelkie działania i inicjatywy podejmowane w kierunku readaptacji społecznej osadzonych były działaniami przemyślanymi i w pełni skoordynowanymi. Otóż w przeciwnym razie trudno mówić o skuteczności oddziaływań resocjalizacyjnych i readaptacyjnych, co między innymi zostało wskazane w raporcie Najwyższej Izby Kontroli z 2015 r., gdzie stwierdzono, że:

zdecydowana większość (93\%) ocenionych programów resocjalizacyjnych nie miała prawidłowo sformułowanych ocen, sposobów i narzędzi pomiaru ich efektywności. W wielu wypadkach umieszczano je w programach jedynie po to, aby spełnić wymogi formalne. Służba Więzienna nie przeprowadzała też analizy skuteczności zastosowanych oddziaływań penitencjarnych, w tym zrealizowanych programów resocjalizacyjnych, ani ich wpływu na przygotowania do readaptacji społecznej, a także przydatności w warunkach wolności (https://www.nik.gov.pl/aktualnosci/nik-o-readaptacji-spolecznej-skazanych-na-wieloletnie-kary-pozbawienia-wolnosci.html).

Dodatkowo na zlecenie Fundacji Sławek przeprowadzono badania ankietowe na grupie 101 byłych skazanych, które wskazały, że:

zdecydowana większość (73\%) byłych więźniów uważa, że działania prowadzone w jednostce penitencjarnej nie wspierały ich wystarczająco skutecznie w powrocie do wolności i odnalezieniu 
się w nowej rzeczywistości. Ponadto zdecydowana większość (96\%) byłych skazanych krytykuje prowadzone w zakładach karnych i aresztach śledczych programy resocjalizacyjne, a zwłaszcza ich małą przydatność i teoretyczny, nieprzystający do życia charakter (https://www.nik.gov.pl/ aktualnosci/nik-o-readaptacji-spolecznej-skazanych-na-wieloletnie-kary-pozbawienia-wolnosci. html, dostęp: 21.09.2017).

\section{Podsumowanie}

Aktywizacja społeczna i zawodowa to determinanty w znaczny sposób wpływające na jakość życia osadzonych w warunkach wolnościowych oraz na ukształtowanie ich celów życiowych - zdecydowanie różniących się od prowadzonego życia przed osadzeniem. Kwestie aktywizacji zawodowej i społecznej między innymi w warunkach probacji podejmowane są od lat przez wielu wybitnych naukowców (Bałandynowicz, Kieszkowska i in.).

Celem nadrzędnym działań aktywizacyjnych jest przede wszystkim działanie prewencyjne i dążenie do pełnego usamodzielnienia się w środowisku wolnościowym. Cel ten jest niezwykle trudny do osiągnięcia, co podkreślają chociażby dane NIK wskazujące, że

pośród niemal 214 tys. skazanych zwolnionych w okresie objętym kontrolą (tj. od 1 stycznia 2012 r. do 30 listopada 2014 r.), do zakładów karnych lub aresztów „wróciło” prawie 4900 osób (2,3\% zwolnionych). W przypadku skazanych na kary wieloletniego pozbawienia wolności odsetek ten jest znacznie wyższy: ze zwolnionych w analogicznym okresie blisko 13 i pół tysiąca skazanych na kary pięciu lub więcej lat za kraty wróciło ponad 1760 osób (13\%) (https://www.nik.gov.pl/aktualnosci/ nik-o-readaptacji-spolecznej-skazanych-na-wieloletnie-kary-pozbawienia-wolnosci.html, dostęp: 23.09.2017).

Odnosząc się do powyższych danych, wyraźnie widać, że problem powrotu na drogę przestępczą jest problemem na szeroką skalę, a liczba osób ponownie odbywających karę pozbawienia wolności jest znaczna. Dlatego też uważam, że ukierunkowanie na aktywizację społeczną i zawodową powinno być działaniem przede wszystkim w pełni skoordynowanym, gdyż tylko wówczas może być działaniem profesjonalnym. Należy pamiętać, że podstawowymi czynnikami determinującymi proces usamodzielnienia skazanych w warunkach wolnościowych jest posiadanie miejsca zamieszkania oraz pracy. Prowadzone przeze mnie badania potwierdzają, że bez tych dwóch czynników proces usamodzielnienia i reintegracji ze środowiskiem jest bardzo utrudniony, a czasem wręcz niemożliwy. Robert J. Sampson i John H. Laub podkreślają, że za pomocą dobrej pracy sprawcy przestępstw mogą modyfikować swoje zachowania w kierunku bardziej prospołecznych oraz stabilizować swoją sytuację życiową, choćby poprzez możliwość legalnego zarobku (Barczykowska 2015: 251). Wynika z tego, że priorytetowym działaniem wpływającym na jakość procesu readaptacji powinno być umożliwienie zatrudnienia osadzonym, nie tylko w jednostkach penitencjarnych, ale 
przede wszystkim w warunkach wolnościowych (oczywiście jeśli są spełnione wszelkie niezbędne przesłanki formalne) dla osadzonych w trakcie odbywania kary. Wówczas takie działanie jest szansą na przełamanie barier i stereotypowego postrzegania osób osadzonych, zwłaszcza w kategorii jednej roli - roli przestępcy, dewianta, kryminalisty. Kredyt zaufania ze strony społeczeństwa, umożliwienie zatrudnienia, bezpieczne miejsce zamieszkania, niestygmatyzowanie i nieocenianie przez pryzmat „błędów przeszłości” to elementy niezbędne w przebiegu procesu readaptacji i ograniczenia powrotu do przestępczego stylu życia.

\section{Bibliografia}

Ambrozik W. (2008). Readaptacja spoteczna i reorganizacja środowisk lokalnych jako warunek skuteczności oddziaływań resocjalizacyjnych, w: B. Urban, J.M. Stanik (red.), Resocjalizacja, t. 2. Wydawnictwo Naukowe PWN, Warszawa.

Bałandynowicz A. (2010). Wielopasmowa koncepcja resocjalizacji z udziałem społeczeństwa. „Resocjalizacja Polska”, 1: 121-156.

Barczykowska A. (2015). Zastosowanie modelu RNR w diagnozie resocjalizacyjnej dorostych sprawców przestępstw - rozwiazania angielskie. Wydawnictwo Naukowe UAM, Poznań.

Bauman Z. (2010). Europa niedokończona przygoda. Wydawnictwo Literackie, Kraków.

Dubiński M. (2005). Sentencje łacińskie. Wydawnictwo Astrum, Warszawa.

Fidelus A. (2009). Integracja społeczna podstawa procesu readaptacji bytych przestępców. „Probacja”, 2: 37-48.

Gawęcka M. (2004). Koncepcja empowerment jako alternatywny paradygmat pracy socjalnej, w: J. Brągiel, P. Sikora (red.), Praca socjalna - wielość perspektyw. Rodzina - multikulturowość - edukacja. Wydawnictwo Uniwersytetu Opolskiego, Opole.

Gulczyńska A., Granosik M. (red.) (2014). Empowerment w pracy socjalnej. Praktyka i badania partycypacyjne. Centrum Rozwoju Zasobów Ludzkich, Warszawa.

Gucwa-Porębska K. (2015). Formy wsparcia dla osób skazanych przedterminowo opuszczających zakłady karne. Oficyna Wydawnicza Impuls, Kraków.

http://sw.gov.pl/pl/ministerialny-program-pracy-wiezniow (dostęp: 29.06.2017).

http://sw.gov.pl/pl/o-sluzbie-wieziennej/edukacja-skazanych/ (dostęp: 20.09.2017).

https://www.nik.gov.pl/aktualnosci/nik-o-readaptacji-spolecznej-skazanych-na-wieloletnie-kary-pozbawienia-wolnosci.html (dostęp: 21.09.2017).

Kieszkowska A. (2012a). Probacja szansą dla osób karanych na poprawę własnego życia wśrodowisku lokalnym, w: B. Urban, M. Konopczyński (red.), Profilaktyka i probacja w środowisku lokalnym. Wydawnictwo Uniwersytetu Jagiellońskiego, Kraków.

Kieszkowska A. (2012b). Wolność, wybór, odpowiedzialność $i$ zobowiazanie przed soba i grupa $w$ warunkach probacji, w: W. Ambrozik, A. Kieszkowska (red.), Tożsamość grupowa dewiantów a ich reintegracja społeczna, cz. II. Oficyna Wydawnicza Impuls, Kraków. 
Musidłowski R. (2007). Znaczenie aktywności własnej skazanych w przygotowaniu do życia po zwolnieniu z zakładu karnego, w: B. Skafiriak (red.), Pomoc postpenitencjarna w kontekście strategii działań resocjalizacyjnych. Oficyna Wydawnicza Impuls, Kraków.

Porębska K. (2010). Pozytywne i negatywne czynniki determinujące proces readaptacji społecznej osób opuszczających zakłady karne, w: F. Kozaczuk (red.), Zachowania przestępcze - przyczyny i zapobieganie. Wydawnictwo Uniwersytetu Rzeszowskiego, Rzeszów: 470-487.

Rozporządzenie Ministra Sprawiedliwości z dnia 9 kwietnia 2004 r. w sprawie szczegółowych zasad zatrudniania skazanych (Dz.U. 9.04.2004 Nr 27, poz. 242).

Rozporządzenie Ministra Sprawiedliwości z 3 stycznia 2012 r. w sprawie Funduszu Pomocy Osobom Pokrzywdzonym i Pomocy Postpenitencjarnej (Dz.U. z 2012 r., poz. 49).

Stępniak P. (2008). Pomoc społeczna i pomoc postpenitencjarna jako wsparcie społecznej readaptacji skazanych. Pojęcie, geneza i rozwój, w: B. Urban, J.M. Stanik (red.), Resocjalizacja, t. 2. Wydawnictwo Naukowe PWN, Warszawa.

Szymańska M. (2007). Znaczenie pracy w życiu człowieka, w: M. Gwoździcka-Piotrowska, J. Wołejszo, A. Zduniak (red.), Edukacja w społeczeństwie „ryzyka”, bezpieczeństwo jako wartość. Wydawnictwo Wyższej Szkoły Bezpieczeństwa, Poznań.

Ustawa z dnia 6 czerwca 1997 r. Kodeks karny wykonawczy (Dz.U.1997.90.557).

Wiatrowski Z. (1997). Podstawy pedagogiki pracy. Wydawnictwo Uczelniane WSP, Bydgoszcz. 